\title{
MODELLING AND INVESTIGATING THE EFFECT OF INPUT PARAMETERS ON SURFACE ROUGHNESS IN ELECTRICAL DISCHARGE MACHINING OF CK45
}

\author{
Saeed Daneshmand, Ali Akbar Lotfi Neyestanak, Vahid Monfared
}

Original scientific paper

Electrical discharge machining is an unconventional machining process in which successive sparks are applied to machine the electrically conductive materials. Any changes in electrical discharge machining parameters lead to the pieces with distinct surface roughness. The electrical discharge machining process is well applied for high hardness materials or when it is difficult to use traditional techniques to do material removing. Furthermore, this method is widely applied in industries such as aerospace, automobile, moulding, and tool making. CK45 is one of important steels in industry and electrical discharge machining can be considered as a proper way for its machining because of high hardness of CK45 after thermal operation of the electrical discharge machining process. Optimization of surface roughness as an output parameter as well as electrical discharge machining parameters including current, voltage and frequency for electrical discharge machining of CK45 have been studied using copper tools and kerosene as the dielectric. For such a purpose and to achieve the precise statistical analysis of the experiment results design of experiment was applied while non-linear regression method was chosen to assess the response of surface roughness. Then, the results were analysed by means of ANOVA method and the machining parameters with more effects on the desired outputs were determined. Finally, mathematical model was obtained for surface roughness.

Keywords: CK45 steel; current; design of experiments; electrical discharge machining; frequency; non-linear regression; surface roughness

Modeliranje i ispitivanje učinka ulaznih parametara na površinsku hrapavost u obradi CK45 električnim pražnjenjem

Izvorni znanstveni članak

Obrada električnim pražnjenjem je neuobičajeni postupak strojne obrade u kojemu se sukcesivno iskrenje primjenjuje u obradi materijala koji provode elektricitet. Svaka promjena parametara električnog pražnjenja rezultira promjenom površinske hrapavosti uzoraka. Obrada elektičnim pražnjenjem se uspješno primjenjuje kod materijala visoke tvrdoče ili kada se za skidanje čestica teško mogu primijeniti tradicionalne metode. Nadalje, ova se metoda uvelike primjenjuje u aeroindustriji, proizvodnji automobila, oblikovanju, izradi alata. CK45 je važan čelik u industriji i obrada električnim pražnjenjem može se za njega smatrati odgovarajućom zbog postizanja visoke tvrdoće nakon toplinske obrade postupkom električnog pražnjenja. Optimizacija površinske hrapavosti kao izlazni parametar kao i parametri postupka električnim pražnjenjem uključujući struju, napon i frekvenciju, analizirani su primjenom alata od bakra i kerozena kao dielektrika. U tu svrhu, te kako bi se postigla uspješna statistička analiza eksperimentalnih rezultata, primijenjen je plan pokusa te ne-linearna metoda regresije za procjenu površinske hrapavosti. Zatim su se rezultati analizirali pomoću metode ANOVA te odredili parametri obrade s više učinka na željeni rezultat. Na kraju, dobiven je matematički model za površinsku hrapavost.

Ključne riječi: čelik CK45; frekvencija; ne-linearna regresija; obrada električnim pražnjenjem; plan eksperimenta; površinska hrapavost; struja

\section{Introduction}

Nowadays, CK45 is an important material and widely applied in moulding and military industries. Machining of this steel imposes a high cost and numerous problems after a thermal operation which increases hardness and tool wear resistance. Moreover, surface roughness of the machined piece greatly influences the quality of the generated pieces (machined parts) in the moulding industry. One of the methods which is appropriate for machining of the alloys and is not dependant on the hardness and strength of the workpiece is electrical discharge machining (EDM) [1]. EDM is the process of machining electrically conductive materials by using precisely controlled sparks that occur between an electrode and a workpiece in the presence of a dielectric fluid. The electrode may be considered as the cutting tool [2]. EDM differs from most chip-making machining operations in that the electrode does not make physical contact with the workpiece for material removal. Since the electrode does not contact the workpiece, EDM has no tool force. The electrode must always be spaced away from the workpiece by the distance required for sparking, known as the sparking gap [3]. Should the electrode contact the workpiece, sparking will cease and no material will be removed. The spark removes material from both the electrode and workpiece, which increases the distance between the electrode and the workpiece at that point. EDM is a thermal process; material is removed by heat. The area heated by each spark is very small so the dielectric fluid quickly cools the vaporized material and the electrode and workpiece surfaces. However, it is possible for metallurgical changes to occur from the spark heating the workpiece surface [4]. EDM is a complex process that includes many input and output parameters [5]. On the other hand, formation of multiple holes on the workpiece surface because of EDM nature and increase in surface roughness of workpiece is considered as one of the main problems in EDM process. Since the dimension of the generated holes is influenced by different input parameters, controlling these parameters is so challenging to reach to the surface quality and precise and predetermined dimensions. The more precise ways to reduce surface roughness of different materials are now being investigated. Lee et.al studied the effects of input parameters of EDM process to machine tungsten carbide in 2001. They reported that the best choice is copper electrode and the best machining performance occurs when the electrode polarity is the cathode and the workpiece polarity is the anode [6]. Ashish investigated the optimum value of input process parameters including pulse current, voltage, gap and pulse time to achieve maximum material removal rate and minimum tool wear rate by using the Taguchi method for a carbon composite sample [7]. Kibria et al. studied the effect of different dielectrics (deionized water, kerosene, boron carbide powder dissolved in oil) on surface roughness and the side gap produced between tool and workpiece using a 
titanium alloy Ti-6AL-4V workpiece and by means of tungsten tool in EDM process [8]. According to their report in comparison with deionized water, kerosene and boron carbide dissolved in oil the lowest surface roughness and side gap is for deionized water and the largest amount is in the case of boron carbide dissolved in oil. Lin et.al did researches on the way of machining as well as flexural strength of tungsten carbide by considering the electrical discharge energy in EDM process [9]. They concluded that if the electrical discharge energy of material removal rate increases, surface roughness and superficial cracks meaningfully rise and subsequently decrease flexural strength of workpiece. Ghanem et al. analysed the effect of pulse current on the surface accuracy of steel types $\mathrm{X} 155 \mathrm{CrMoV} 12$ and $\mathrm{X} 2 \mathrm{CrNiMo} 17$ in 2003 [10]. Tomadi et al. showed that the quality of the workpiece surface machined by EDM is significantly dependent on the energy of each spark by doing experiments on surface roughness in the EDM process of tungsten carbide [11]. In addition, according to their experiments increase in pulse off time leads to increase in spark discharge current of surface roughness. The present article focuses on studying the effects of parameters such as spark current intensity, frequency and voltage on surface roughness as an output parameter in machining operation of CK45 and presenting a model for surface roughness determination and preventing the conventional trial and error method.

\section{Design of experiments}

Design of Experiments (DOE) is one of the useful techniques to find the main effective variables of the desired qualitative characteristics of the process [12]. Now there are four DOE methods available: classical, Taguchi, full factorial and RMS designs, each of them with its own application but analysis through Taguchi method is easier compared with others. There is some software with their specific computational methods though they almost all reach the same results. In this study, DOE was done via full factorial design in Mintab software and the effects of the most important machining parameters i.e. spark discharge current, spark voltage and frequency on surface roughness were investigated. Pulse frequency is obtained according to Eq. (1).

$$
f=\frac{1}{T_{\text {on }}+T_{\text {off }}},
$$

where: $T_{\text {on }}$ is pulse on time, $T_{\text {off }}$ is pulse off time.

Table 1 Input parameters of EDM and variation levels

\begin{tabular}{|l|c|}
\hline \multicolumn{1}{|c|}{ Experiment Variable } & Descriptions \\
\hline Dielectric fluid & Oil flux EL F2 \\
\hline Discharge current (A) & $4,8,12$ \\
\hline Pulse frequency $(\mathrm{kHz})$ & $1,5,10$ \\
\hline Discharge voltage (V) & $50,75,100$ \\
\hline Tool polarity & Negative $(-)$ \\
\hline
\end{tabular}

In these experiments, tool and workpiece were considered negative and positive respectively. Tab. 1 gives the ways to do experiments, adjusting the input parameters of the experiments and the variation levels.

\section{Experiments}

This section summarizes the equipment used in the experiments of EDM, workpiece materials, the applied tools and design parameters.

\subsection{Workpiece}

CK45 steel was used as the workpiece in this experiment for electrical discharge machining. Because of large amount of carbon content in its structure CK45 has high erosion resistance and a hardness of about $50 \mathrm{HRC}$ (Rockwell C). This steel is widely applied in industries such as production of cutting mould, blades, cutting tools, etc. Tab. 2 gives the mechanical and physical properties of CK45. The workpiece dimension is $5 \times 150 \times 150 \mathrm{~mm}^{3}$.

Table 2 Mechanical and physical properties of CK45

\begin{tabular}{|l|c|}
\hline \multicolumn{1}{|c|}{ Tensile strength } & $850 \mathrm{MPa}$ \\
\hline Elongation & $8 \div 25 \%$ \\
\hline Yield strength & $510 \mathrm{MPa}$ \\
\hline Melting temperature & $1450 \div 1510^{\circ} \mathrm{C}$ \\
\hline Density & $7700 \mathrm{~kg} / \mathrm{m}^{3}$ \\
\hline Resistivity & $0,55 \mathrm{Ohm} \cdot \mathrm{mm}^{2} / \mathrm{m}$ \\
\hline Thermal conductivity & $25 \mathrm{~W} / \mathrm{m} \cdot \mathrm{K}$ \\
\hline Specific heat & $460 \mathrm{~J} / \mathrm{kg} \cdot \mathrm{K}$ \\
\hline
\end{tabular}

\subsection{Electrode tool}

Copper was selected as the material of the electrode tool with a diameter of $10 \mathrm{~mm}$ and a length of $30 \mathrm{~mm}$. The workpiece was prepared for the experiments after cutting and then stoning (grinding) both sides of the electrode tool. It was connected to the negative pole of the system.

\subsection{Dielectric}

Kerosene was used as dielectric in these experiments.

\subsection{EDM system}

The PISHTAZAN EDM system was applied to the maximum current of 100 ampere. Tab. 3 shows its specifications.

Table 3 EDM Machine specification

\begin{tabular}{|l|c|c|}
\hline \multicolumn{1}{|c|}{ Specifications } & Units & Dimensions \\
\hline Work tank size & $\mathrm{mm}$ & $1000 \times 600 \times 500$ \\
\hline Cross travel $x$ - longitudinal & $\mathrm{mm}$ & 400 \\
\hline Cross travel $y$ - longitudinal & $\mathrm{mm}$ & 300 \\
\hline Work table size & $\mathrm{mm}$ & $700 \times 400$ \\
\hline Spindle travel and head stock travel & $\mathrm{mm}$ & 200 \\
\hline Electrode weight & $\mathrm{kg}$ & 100 \\
\hline Max output current & $\mathrm{A}$ & 100 \\
\hline Loading capacity of table & $\mathrm{kg}$ & 500 \\
\hline Fluid tank & liters & 250 \\
\hline Input power rating & $\mathrm{kW}$ & 10 \\
\hline
\end{tabular}

\section{Surface roughness measurement}

Surface roughness meter DIAVITE COMPACT with a precision of $0,001 \mu \mathrm{m}$ was used to measure the surface roughness of the machined pieces. 


\section{Design parameters, experiments and analyzing response variable}

The effects of three input variables including intensity of spark discharge current; spark voltage and frequency on the process response i.e. surface roughness were analysed in the present study. The most important parameter for pieces after machining operation is surface roughness. Surface roughness was measured by surface roughness meter DIAVITE COMPACT. Surface roughness of the samples was measured with a precision of $0,01 \mu \mathrm{m}$ according to $R a$ standard. $L_{\mathrm{c}}=0,8 \mathrm{~mm}, L_{\mathrm{m}}=$
3,2 $\mathrm{mm}$ and $L_{\mathrm{t}}=4,8 \mathrm{~mm}$ were chosen as measuring parameters of surface roughness. Where: $L_{\mathrm{t}}$ - Traverse length, $L_{\mathrm{m}}$ - Total length of traverse and $L_{\mathrm{c}}$ - Cut off length.

The probe of the system moved 6 times in each 0.8 $\mathrm{mm}$. Due to the probe acceleration surface roughness was not measured at the first and the end. Measurement of surface roughness was repeated 3 times and the average was calculated in order to reach the more accurate value. The obtained results are given in Tab. 4 .

Table 4 Design of experiments and surface roughness results

\begin{tabular}{|c|c|c|c|c|}
\hline Test number & Discharge current (A) & Discharge voltage $(\mathrm{V})$ & Pulse frequency $(\mathrm{kHz})$ & Surface roughness $R a(\mu \mathrm{m})$ \\
\hline 1 & 4 & 50 & 1 & 2,82 \\
\hline 2 & 4 & 50 & 5 & 2,33 \\
\hline 3 & 4 & 50 & 10 & 2,01 \\
\hline 4 & 4 & 75 & 1 & 3,03 \\
\hline 5 & 4 & 75 & 5 & 2,53 \\
\hline 6 & 4 & 75 & 10 & 2,22 \\
\hline 7 & 4 & 100 & 1 & 3,38 \\
\hline 8 & 4 & 100 & 5 & 2,83 \\
\hline 9 & 4 & 100 & 10 & 2,55 \\
\hline 10 & 8 & 50 & 1 & 3,88 \\
\hline 11 & 8 & 50 & 5 & 3,50 \\
\hline 12 & 8 & 50 & 10 & 3,31 \\
\hline 13 & 8 & 75 & 1 & 4,00 \\
\hline 14 & 8 & 75 & 5 & 3,50 \\
\hline 15 & 8 & 75 & 10 & 3,30 \\
\hline 16 & 8 & 100 & 1 & 4,41 \\
\hline 17 & 8 & 100 & 5 & 3,70 \\
\hline 18 & 8 & 100 & 10 & 3,22 \\
\hline 19 & 12 & 50 & 1 & 5,90 \\
\hline 20 & 12 & 50 & 5 & 5,65 \\
\hline 21 & 12 & 50 & 10 & 5,11 \\
\hline 22 & 12 & 75 & 1 & 5,05 \\
\hline 23 & 12 & 75 & 5 & 5,50 \\
\hline 24 & 12 & 75 & 10 & 5,45 \\
\hline 25 & 12 & 100 & 1 & 6,33 \\
\hline 26 & 12 & 100 & 5 & 5,55 \\
\hline 27 & 12 & 100 & 10 & 5,00 \\
\hline
\end{tabular}

\section{Analysis of surface roughness response}

Statistical analysis of process by DOE technique was utilized to precisely analyse the results of the experiments, determine the main and more effective parameters and mutual effects in addition to assess the responses. Statistical analysis of these results was performed by Minitab software and the proper regression model was derived. If $R^{2}>0,950$ and $R^{2}$ (adjusted) > 0,950 then statistical analysis of data implies the accuracy of the regression model [13]. The values of $\mathrm{R}^{2}$ and $\mathrm{R}^{2}$ (adjusted) given in table 5 emphasize the accuracy of the regression models and the values measured for surface roughness.

According to this table, it can be concluded that the quadratic regression model has a smaller error in comparison with the first degree (linear) regression model so the later one is not acceptable. Therefore, the second degree regression model is recommended for doing experiments. Eq. (2) generally shows the regression of surface analysis to estimate the response. $I, F, V$ and $R a$ are respectively pulse current (A), pulse frequency $(\mathrm{Hz})$, voltage $(\mathrm{V})$ and surface roughness $(\mu \mathrm{m})$.

Table 5 Values of $R^{2}$ and $R^{2}$ (adjusted) of the regression models

\begin{tabular}{|c|c|c|}
\hline $\begin{array}{c}\text { Quadratic } \\
\text { regression }\end{array}$ & First order regression & Regression models \\
\hline 0,968 & 0,859 & $R$ Square \\
\hline 0,951 & 0,847 & Adjusted $R$ Square \\
\hline
\end{tabular}

$R a=3,18-0,094 \cdot I-0,0121 \cdot V-0,127 \cdot F-$

$-0,00115 \cdot I \cdot V-0,000818 \cdot V \cdot f+0,00316 \cdot I \cdot F+$

$+0,0326 \cdot I^{2}+0,000198 \cdot V^{2}+0,00707 \cdot F^{2}$.

To verify this equation and considering $I=10, V=75$ and $F=5$ the value of surface roughness obtained by theoretical equation was 5,38 and practically was 5,12 which demonstrates an error of about $5 \%$ that is acceptable. 


\section{Effects of input parameters on surface roughness}

Fig. 1 illustrates the effect of current, frequency and voltage of the spark on surface roughness of CK45. According to this figure and Eq. (1), an increase in pulse on time and subsequent reduction of frequency enhances surface roughness because rise in each spark's energy is a result of increase in pulse on time and eventually leads to growth of the holes generated by machining. As seen in Fig. 1, Ra-I curve has a greater slope compared with $R a-V$ and $R a-f$ curves so as machining current rises it causes more significant impact on surface roughness in comparison with increases in pulse on time or reduction of frequency. It shows that the amount of discharged energy of each spark in the EDM process plays a more important role than the density of spark energy.

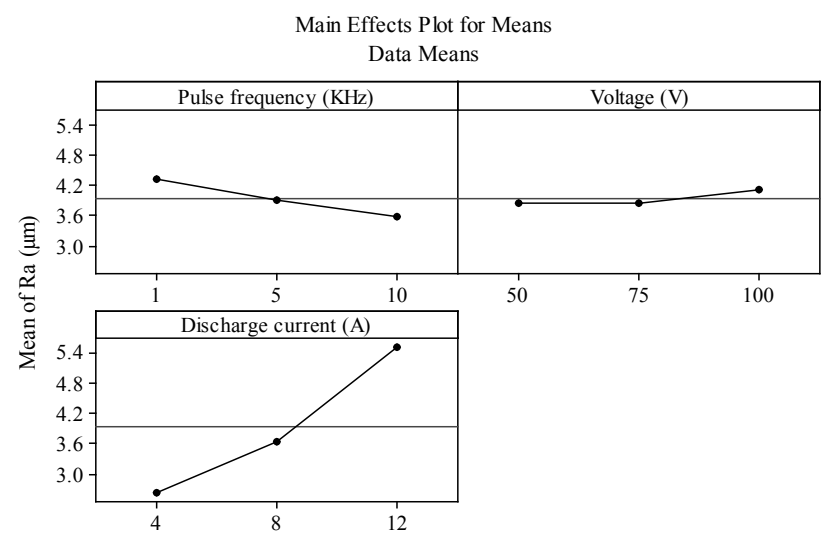

Figure 1 Effect of input parameters on surface roughness

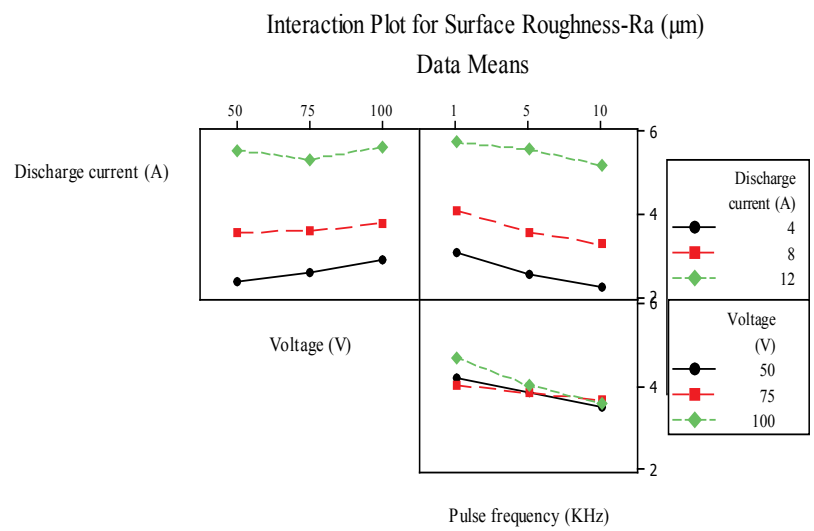

Figure 2 Simultaneous effects of input parameters on surface roughness

On the other hand, an increase in voltage has no considerable effect on surface roughness. Increase in voltage causes an increase in the stability of plasma channel and it lessens the deviation of the location where the effect of sparks is seen one side on the tool and the other side on the workpiece. So, the deviation of the spark is reduced and consequently increase in voltage has no great effect on the surface roughness. The time required for energy absorption of workpiece increases when pulse on time is increased. As a result, more material is removed from the workpiece and surface roughness will be increased. Moreover, pulse off time has no significant effect on the surface roughness and it depends more on pulse on time and current of spark. Considering Eq. (1), it would be possible to achieve the desired surface roughness by changing these two parameters.

Fig. 2 demonstrates the simultaneous effect of input parameters on surface roughness. Considering this figure, surface roughness is highly influenced if current and frequency simultaneously rise. Great slope of each curve indicates mark able effect of relevant parameter on surface roughness. Simultaneous effect of current and frequency of surface roughness is illustrated in Fig. 3. As seen in this figure, surface roughness of the workpiece is increased by decreasing the frequency and increasing the current. The best surface quality will be obtained at low current and pulse on time that both parameters lead to increase in frequency.

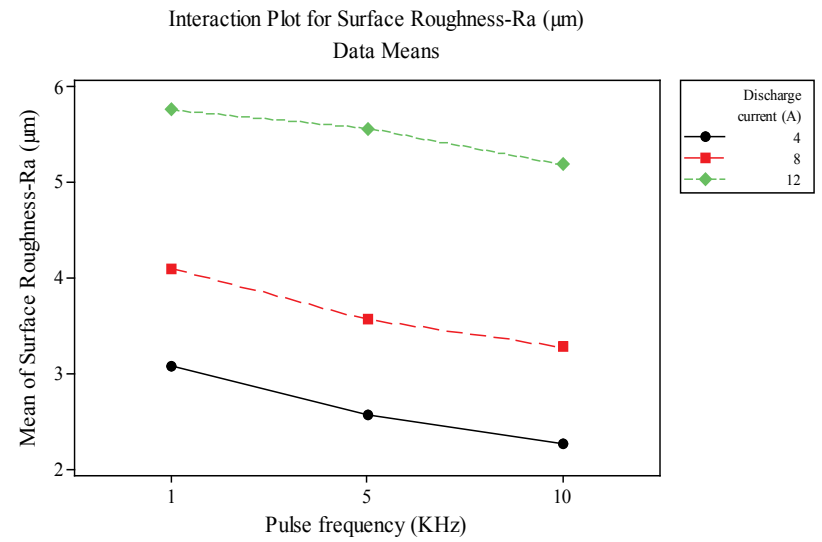

Figure 3 Effect of current and voltage on surface roughness

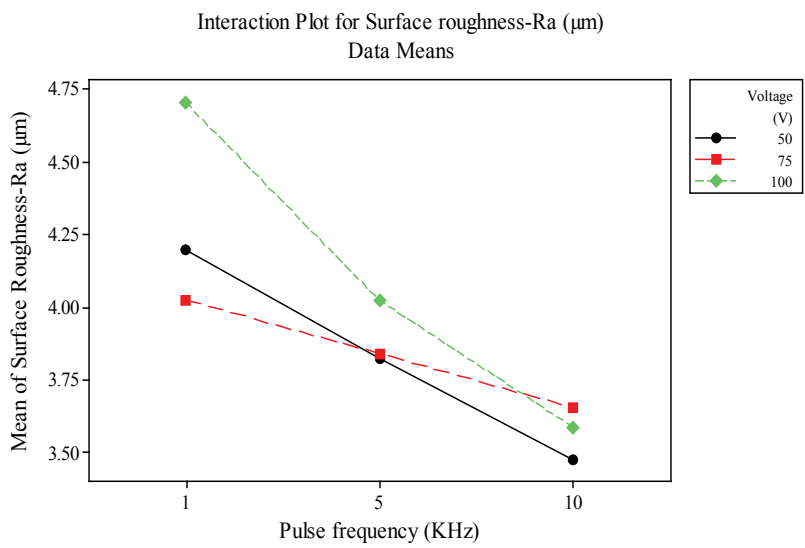

Figure 4 Simultaneous effects of voltage and frequency on surface roughness

Fig. 4 shows the simultaneous effect of voltage and frequency on surface roughness. According to this figure, increase in pulse on time and reduction of frequency rises surface roughness at a fixed voltage.

The mutual effects of pulse current and frequency are indicated in Fig. 5. According to the results, increase in pulse current at a specific frequency rises surface roughness and the minimum surface roughness will be obtained at the lowest current and greatest amount of frequency.

Variations in surface roughness of CK45 samples are shown in Figs. 6, 7 and 8 by means of surface plots. The effects of current and voltage, current and frequency, and voltage and frequency are respectively shown in Figs. 6, 7 , and 8. Analysis of data reveals that pulse current has greater effect than other parameters. Generally, surface 
plot for the response of surface roughness versus current and voltage indicates that increase in current and voltage rises surface roughness. When voltage increases the electric field gap in a plasma channel also increases and it leads to the presence of larger amounts of electrons and ions. As a result, more ions with a greater deal of energy collide the workpiece and increase surface roughness [14].

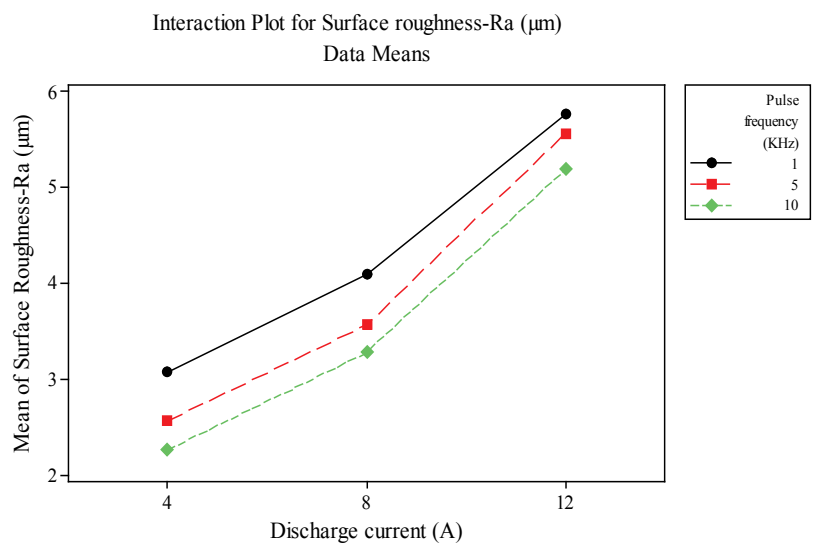

Figure 5 Simultaneous effect of current and frequency on surface roughness

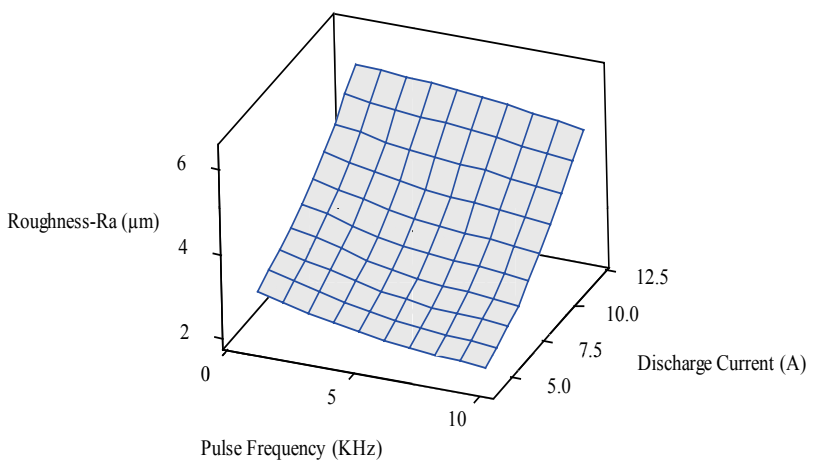

Figure 6 Effect of current and frequency on surface roughness

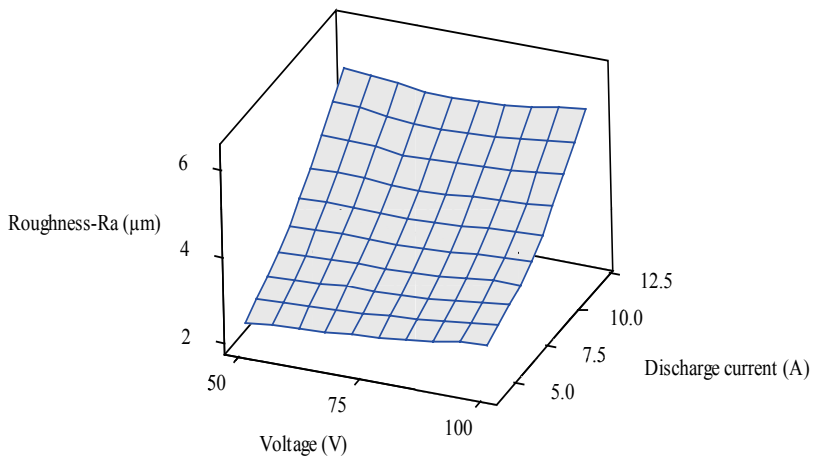

Figure 7 Effect of current and voltage on surface roughness

Fig. 6 shows that since pulse in the time increases frequency decrease and slope of surface roughness increases. Considering the investigations, it seems that the plasma channel expands at the location of electric arc and inside the dielectric with reduction of frequency or increase in pulse on time in each machining cycle which influences the increase in surface roughness [14]. According to Fig. 7, the effect of current on surface roughness is more noticeable than the effect of frequency. As obviously shown in Fig. 8, there is an inverse relationship between frequency and surface roughness and increase in voltage has no great effect on surface roughness. The desired surface roughness will be obtained by changing the frequency and having a fixed voltage.

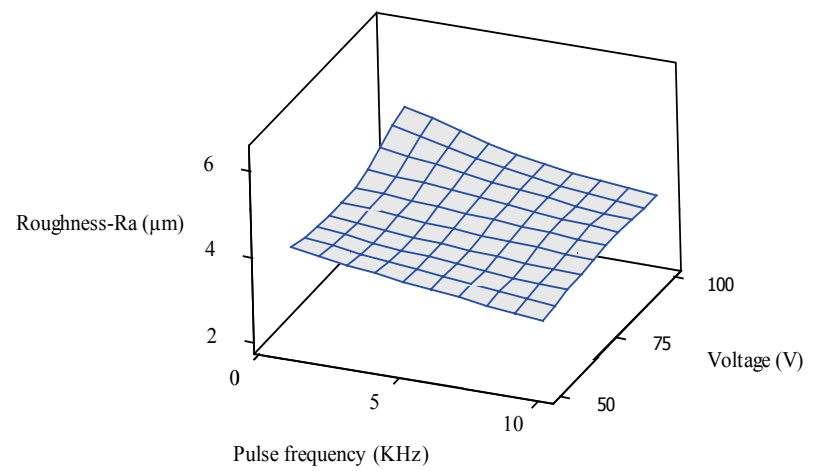

Figure 8 Effect of voltage and frequency on surface roughness

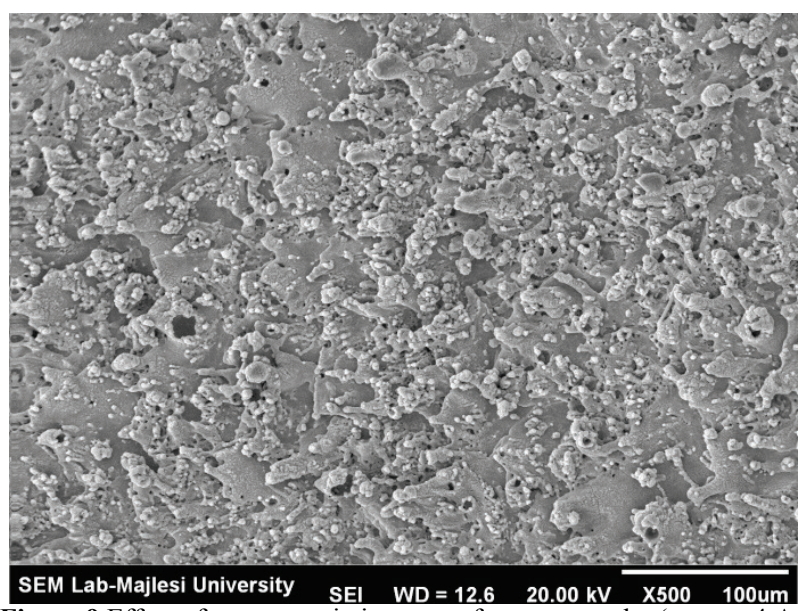

Figure 9 Effect of current variation on surface topography (current $4 \mathrm{~A}$, voltage $75 \mathrm{~V}$, pulse frequency $1 \mathrm{kHz}$ )

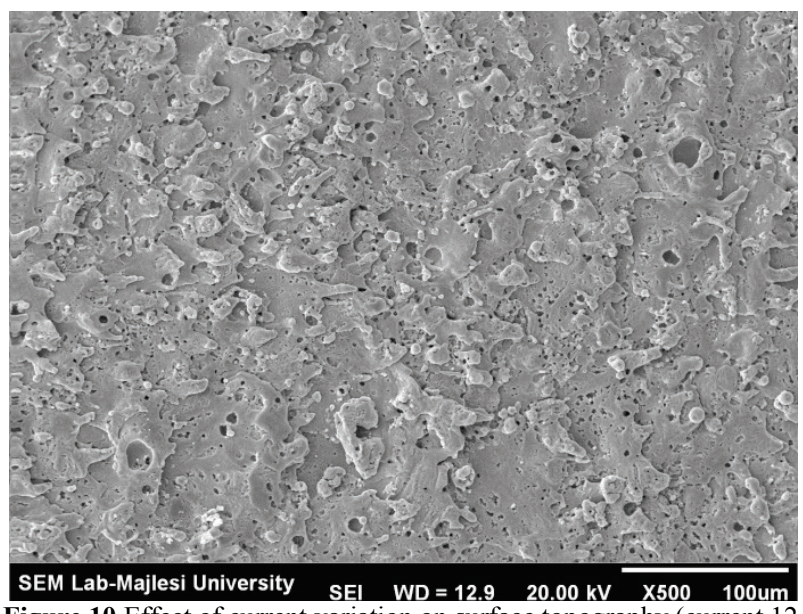

Figure 10 Effect of current variation on surface topography (current 12 A, voltage $75 \mathrm{~V}$, pulse frequency $1 \mathrm{kHz}$ )

\section{Surface topography}

Since fast melting of the workpiece surface occurs during the electrical discharge process and then its fast freezing because of the presence of dielectric surface defects like crack, hole, residual stresses, pits and holes create on the workpiece surface. Fast freezing of the workpiece surface and the presence of oil based dielectric produce a martensite layer on the workpiece surface. 
These surface defects increase surface roughness, abrasion resistance, corrosion, and micro cracks on the workpiece surface. The effect of pulse current on the surface topography is illustrated in Figs. 9 and 10 with a resolution of 500 and the same machining conditions. According to these figures, an increase in current leads to increase in spark energy as well as the depth of the holes generated on the workpiece surface and it consequently increases surface roughness, pits and holes, and surface cracks. The concentration of particles between tool and workpiece rises with an increase in current and pulse on time and consequently it brings more instability either in the form of short circuit or arc discharge in EDM and the machined surface becomes rougher and more uneven. Considering the topography given in these figures, surface roughness and surface quality are changed by variation of pulse current and frequency and finally the desired amount will be achieved.

\section{Conclusion}

In the present study, the effects of the main parameters including current, voltage and frequency on the surface roughness as a response variable were analyzed for electrical discharge machining of CK45 steel using kerosene as dielectric and copper electrode. DOE technique with non-linear regression model was used to estimate the process responses. It was concluded that the most important and effective parameter for surface roughness is pulse current. Surface roughness is enhanced with an increase in pulse current because of an increase in spark discharge energy. The following results are obtained after performing experiments and analysis:

1. The proper regression model with an error of about 5 $\%$ is derived by which is calculated surface roughness. Therefore, it prevents industries from conventional trial and error methods.

2. Increase in current and voltage leads to increase in surface roughness while if frequency increases surface roughness decreases.

3. Current is more effective on surface roughness in comparison with the voltage and frequency. Specifically, voltage is not much effective for surface roughness.

4. A simultaneous increase in current and frequency greatly impacts surface roughness.

5. On the other hand, the effect of simultaneous increase in other parameters is negligible.

6. The relation of current and frequency with surface roughness is non linear while it is linear for in voltage.

\section{$9 \quad$ References}

[1] Gostimirovic, M.; Kovac, P.; Sekulic, M.; Skoric, B. Influence of discharge energy on machining characteristics in EDM. // Journal of Mechanical Science and Technology. 26, 1(2011), pp. 173-179. DOI: 10.1007/s12206-011-0922-x

[2] Ghose, J.; Sharma, V.; Kumar, N.; Krishnamurthy, A.; Kumar, S.; Botak, Z. Taguchi-fuzzy based mapping of EDM-machinabilIty of aluminum foam. // Tehnicki vjesnik-Technical Gazette. 18, 4(2011), pp. 595-600.

[3] Abedi, E.; Daneshmand, S.; Lotfi Neyestanak, A. A.; Monfared, V. Analysis and modeling of electro discharge machining input parameters of Nitinol shape memory alloy by De-ionized water and copper tools. // Journal of Electrochemical Science. 9, (2014), pp. 2934-2943.

[4] Elman, C. Jameson. Electrical discharge machining, Society of Manufacturing Engineers, 2001.

[5] Amorim, F. L.; Weingaertner, W. L. Die-sinking electrical discharge machining of a high-strength copper- based alloy for injection molds. // Journal of the Brazilian Society of Mechanical Sciences and Engineering. XXVI, 2(2004), pp. 137-144. DOI: $10.1590 / \mathrm{s} 1678-58782004000200004$

[6] Lotfi Neyestanak, A. A.; Daneshmand, S. The effect of operational cutting parameters on Nitinol-60 in wire electro discharge machining. // Advances in Materials Science and Engineering. (2013), pp. 1-6. DOI: 10.1155/2013/457186

[7] Ashish, M. W.; George, P. M.; Raghunath, B. K.; Manocha, L. M.; Warrierc, A. M. EDM machining of carbon-carbon composite - aTaguchi approach. // Journal of Materials Processing Technology. 145, 1(200), pp. 66-71.

[8] Kibria, G.; Sarkar, B. R.; Pradhan, B. B. Bhattacharyya, B. Comparative study of different dielectrics for micro-EDM performance during microhole machining of Ti-6Al-4V alloy. // Journal of Advanced Manufacturing Technology. 48, 5-8(2010), pp. 557-570. DOI: 10.1007/s00170-009-2298-y

[9] Lin, Y. C.; Hwang, L. R.; Cheng, C. H.; Su, P. L. Effects of electrical discharge energy on machining performance and bending strength of cemented tungsten carbides. // Journal of Materials Processing Technology. 206, 1-3(2008), pp. 491-499. DOI: 10.1016/j.jmatprotec.2007.12.056

[10] Ghanem, F.; Braham, C.; Sidhom, H. Influence of steel type on electrical discharge machined surface integrity. // Journal of Materials Processing Technology. 142, 1(2003), pp. 163-173. DOI: 10.1016/S0924-0136(03)00572-7

[11] Tomadi, S. H.; Hassan, M. A.; Hamedon, Z.; Daud, R.; Khalid, A. G. Analysis of the influence of EDM parameters on surface quality // material removal rate and electrode wear of tungsten carbide, International Multi Conference of Engineers and Computer Scientists / Hong Kong, March 18 $-20,2009$.

[12] Lotfi Neyestanak, A. A.; Daneshmand, S.; Adib Nazari, S. The effect of operational cutting parameters in the wire electro discharge machining (WEDM) on micro hardness of alloy surface layer. // Journal of Advanced Design and Manufacturing Technology. 4, 2(2009), pp. 51-58.

[13] Lee, S. H.; Li, X. P. Study of the effect of machining parameters on the machining characteristics in electrical discharge machining of tungsten carbide. // Journal of Materials Processing Technology. 115, 3(2001), pp. 344358. DOI: $10.1016 / \mathrm{S} 0924-0136(01) 00992-X$

[14] Kao, J. Y.; Tsao, C. C.; Wang, S. S.; Hsu, C. Y. Optimization of the EDM parameters on machining Ti-6Al$4 \mathrm{~V}$ with multiple quality characteristics. // Journal of Advanced Manufacturing Technology. 47, 1-4(2010), pp. 395-402. DOI: 10.1007/s00170-009-2208-3

\section{Authors' addresses}

\section{Saeed Daneshmand}

Department of Mechanical Engineering, Majlesi Branch, Islamic Azad University, Isfahan, Iran

Postal address: 8631656451

E-mail: S.daneshmand@iaumajlesi.ac.ir

\section{Ali Akbar Lotfi Neyestanak}

Department of Engineering, Yadegar -e- Imam Khomeini (RAH) Branch, Islamic Azad University, Tehran, Iran

Vahid Monfared

Department of Mechanical Engineering, Zanjan Branch, Islamic Azad University, Zanjan, Iran 